\title{
Associations of sarcopenia components with physical activity and nutrition in Australian older adults performing exercise training
}

Ewelina Akehurst', David Scott ${ }^{2,3,4}$, Juan Peña Rodriguez ${ }^{5}$, Carol Alonso Gonzalez ${ }^{5}$, Jasmaine Murphy ${ }^{1}$, Helen McCarthy ${ }^{1}$, Sandor Dorgo ${ }^{6}$ and Alan Hayes ${ }^{1,4,7^{*}}$ (iD

\begin{abstract}
Background: The risk of progressive declines in skeletal muscle mass and strength, termed sarcopenia, increases with age, physical inactivity and poor diet. The purpose of this study was to explore and compare associations of sarcopenia components with self-reported physical activity and nutrition in older adults participating in resistance training at Helsinki University Research [HUR] and conventional gyms for over a year, once a week, on average.

Methods: The study looked at differences between HUR $(n=3)$ and conventional $(n=1)$ gyms. Muscle strength (via handgrip strength and chair stands), appendicular lean mass (ALM; via dual energy X-ray absorptiometry) and physical performance (via gait speed over a 4-m distance, short physical performance battery, timed up and go and 400-m walk tests) were evaluated in 80 community-dwelling older adults (mean \pm SD $76.5 \pm 6.5$ years). Pearson correlations explored associations for sarcopenia components with self-reported physical activity (via Physical Activity Scale for the Elderly [PASE]) and nutrition (via Australian Eating Survey).

Results: No differences in PASE and the Australian Recommended Food Score (ARFS) were observed between HUR and conventional gyms, however HUR gym participants had a significantly higher self-reported protein intake $(108 \pm 39 \mathrm{~g}$ vs $88 \pm 27 \mathrm{~g} ; p=0.029)$ and a trend to have higher energy intake $(9698 \pm 3006 \mathrm{~kJ}$ vs $8266 \pm 2904 \mathrm{~kJ} ; p=$ $0.055)$. In both gym groups, gait speed was positively associated with self-reported physical activity $(r=0.275 ; p=$ 0.039 and $r=0.423 ; p=0.044$ for HUR and conventional gyms, respectively). ALM was positively associated with protein $(p=0.047, r=0.418)$ and energy $(p=0.038, r=0.435)$ intake in the conventional gym group. Similar associations were observed for $\mathrm{ALM} / \mathrm{h}^{2}$ in the HUR group. None of the sarcopenia components were associated with ARFS in either gym group.

*Correspondence: alan.hayes@vu.edu.au

${ }^{1}$ Institute for Health and Sport, Victoria University, Footscray, Victoria,

Australia

${ }^{4}$ Australian Institute for Musculoskeletal Science (AIMSS), St Albans, Victoria,

Australia

Full list of author information is available at the end of the article

(c) The Author(s). 2021 Open Access This article is licensed under a Creative Commons Attribution 4.0 International License, which permits use, sharing, adaptation, distribution and reproduction in any medium or format, as long as you give appropriate credit to the original author(s) and the source, provide a link to the Creative Commons licence, and indicate if changes were made. The images or other third party material in this article are included in the article's Creative Commons licence, unless indicated otherwise in a credit line to the material. If material is not included in the article's Creative Commons licence and your intended use is not permitted by statutory regulation or exceeds the permitted use, you will need to obtain permission directly from the copyright holder. To view a copy of this licence, visit http://creativecommons.org/licenses/by/4.0/ The Creative Commons Public Domain Dedication waiver (http://creativecommons.org/publicdomain/zero/1.0/) applies to the data made available in this article, unless otherwise stated in a credit line to the data. 
(Continued from previous page)

Conclusion: Older adults attending HUR and conventional gyms had similar self-reported function and nutrition (but not protein intake). Inadequate physical activity was associated with low gait speed and inadequate nutrition and low protein ingestion associated with low lean mas, even in older adults participating in exercise programs. Optimal physical activity and nutrition are important for maintaining muscle mass and function in older adults.

Keywords: Helsinki University research, Nutrition, Older adults, Sarcopenia, Resistance training

\section{Background}

The risk of progressive decline in skeletal muscle mass and strength, termed sarcopenia, increases with age, chronic disease, physical inactivity and poor diet [1-3]. Nutrition is an important part of muscle mass and function [4-6]. Since muscle function is affected by poor nutrition, hand grip strength (HGS) has become a marker of nutritional status [7-9] and an outcome predictor for nutritional interventions [9]. HGS is a key component of major sarcopenia definitions (the Foundation for the $\mathrm{Na}$ tional Institutes of Health Sarcopenia Project and European Working Group on Sarcopenia in Older People, January 2019 update [EWGSOP2]). HGS has also been correlated with a number of performance measures, including the timed up and go (TUG) test [10], which predicts changes in functional balance [11] and was introduced as part of EWGSOP2 as a measure of sarcopenia severity. Likewise, the $400 \mathrm{~m}$ walk test was introduced within the EWGSOP2 definition to assess mobility and endurance, in conjunction with chair stands (strength) and the well-established sarcopenia component gait speed (GS) [12].

Low protein and energy intakes are linked to sarcopenia $[5,13]$ and benefits of appropriate nutrition have been reported alone and in conjunction with resistance training $[14,15]$. Although the provision of exercise programs in aged-care centres is not uncommon [16-18], there is a lack of data on the relationship between sarcopenia components (muscle strength, lean mass and physical performance) and physical activity levels and nutritional status amongst participants using Helsinki University Research (HUR) and conventional gym equipment.

Our aim was to examine and compare associations of sarcopenia components with self-reported physical activity and nutrition in older adults performing exercise training at HUR and conventional gyms. We hypothesized self-reported physical activity and nutrition would be associated with muscle mass and function, with no differences according to the type of gym being used (HUR or conventional gym training).

\section{Methods}

We applied a cross-sectional design using convenience sampling to observe participants (range 61-91 years of age) that were undergoing training exercises under supervision of exercise physiologists and physiotherapists at four gyms of Uniting AgeWell in Melbourne, Australia. The study looked at differences between HUR $(n=3)$ and conventional $(n=1)$ gyms.

\section{Participants \\ Sample size}

The recruitment for this study came from a pool of approximately 720 existing gym members plus those willing to join the gyms during the study. Using GPower v. 3.1 [19], with muscle mass as the primary end point and an expected $20 \%$ variation around the mean, detecting a $10 \%$ difference with alpha of 0.05 and beta 0.2 would require $n=67$. As mass was the slowest measure to change, this number ensured the ability to identify training-based adaptations in physical function. However, it was planned to recruit as many Uniting AgeWell gym users as were willing to participate by displaying posters in the four participating gyms.

\section{Inclusion criteria and recruitment}

The only inclusion criteria were that the subjects had to be Uniting AgeWell clients who were already gym members or had just joined the gym and were living at home or in Uniting AgeWell residential care. Participants had been assessed as able to exercise safely by Uniting AgeWell staff prior to this study commencing. Thus, there were no specific exclusion criteria as all gym clients who were accepted to take part in the Uniting AgeWell exercise training were eligible to participate, independent of type of training, frequency or duration. All participants that were available for testing were included to maintain the power for the study, thus no specific adherence criteria were required.

\section{Training protocol}

Three sites, Forest Hill, Noble Park (both attached to the residential care) and Oakleigh gyms used HUR equipment, while the fourth site in Hawthorn used the conventional equipment. HUR gyms used HUR equipment, which was developed in Finland in 1989 and uses innovative pneumatic technology and computerised smart card and smart touch systems that record clients' visits and work-outs [20, 21]. The Forest Hill and 
Oakleigh gyms included HUR Active Line equipment, such as pulleys, leg presses, hip abduction/adduction machines, leg flexion/extension machines, chest presses, rhomboid machines, trunk flexion/extension machines and iBalance and NuStep machines. Noble Park, which was the most recently opened facility, had the Premium Line equipment, including an abdominal/back roller and optimal rhomb (seated device to exercise upper body optimised for older adults). The conventional gym in Hawthorn used standard equipment, such as dumbbells, barbells, kettlebells, TheraBands, steps, medicine balls, treadmills, exercise bikes, an elliptical cross trainer and a cable weight machine. Training duration was generally 1 $\mathrm{h}$, and the frequency varied depending on individual programs (usually once or twice per week), with programs ranging $2-3$ sets with $8-20$ repetitions.

\section{Sarcopenia components}

\section{Appendicular lean mass (ALM)}

Dual-energy X-ray absorptiometry (DXA) (Hologic Horizon A, MeasureUp, Melbourne) was used to measure weight, ALM (kg), which is defined as the sum of lean soft-tissue mass from both the arms and legs [22] and a stadiometer (Charder HM200P, Charder Electronic Co. Ltd., Tachung City, Taiwan) to measure height. Absolute and normalised parameters were reported, as changes in lean mass and body size may affect loss of muscle mass with age [23].

\section{Hand grip strength (HGS)}

HGS (kg) was tested with subjects seated upright, with elbow bent $90^{\circ}$ and forearm resting on an armrest support, using a handgrip dynamometer (Jamar Plus+, SI Instruments, Adelaide, Australia). Following a practice test, two trials were recorded for each hand with the subject squeezing as hard as possible and the highest score of all six tests was used for analysis [24].

\section{Short physical performance battery (SPPB)}

The SPPB was used to assess lower extremity function in older adults [25]. It consisted of balance with different stances, GS timed over a 4-m course at normal speed, and a five-chair stand (CS) test. The practice attempt was a single CS without a stopwatch. Participants were asked to fold their arms across chest and stand up from a chair once. If successful, five rises as fast as possible were timed from the first sitting position to the end of the fifth stand. Time was recorded using a sports stopwatch (cat. no. XC027, Jaycar, Melbourne, Australia).

\section{Timed up and go (TUG)}

Mobility, balance and agility were tested via the TUG (s) test at normal speed, which consisted of rising from seated position, walking three metres to a cone, turning around it, walking back and sitting down on the chair again. Participants walked at normal speed and the chair was positioned with back against a wall for safety. Following an initial trial, two further attempts were recorded and the shortest time was reported in the study [26].

\section{0-m walk}

Mobility and cardiovascular fitness were assessed with a $400 \mathrm{~m}$ walk test ( $\mathrm{min}$ ). The standard course is $20 \mathrm{~m}$ with participants walking up around a cone and back 10 times as fast as possible. Due to constraints of available space, the course was $10 \mathrm{~m}$ long walked 20 times. Only one attempt at this test was allowed at the end of the testing day.

\section{Self-reported physical activity status}

Physical activity status over the past week (not including any gym sessions) was assessed via a 12-item Physical Activity Scale for the Elderly (PASE) questionnaire, including activities such as walking and light, moderate or strenuous sport over the previous week [27]. Total PASE scores were calculated by multiplying the amount of time spent on each activity by respective weights and adding up all activities, usually ranging between 0 and 360 , with higher scores signifying higher physical activity levels [27]. Written permission was obtained to use PASE in this study.

\section{Self-reported nutritional status}

Participants were also asked to complete the Australian Eating Survey (AES) for adults, providing a comparison of food and nutritional intake with nutrition targets in the past 3-6 months. In this study, we analysed the Australian Recommended Food Score (ARFS), protein and energy intake derived from the AES. The ARFS has been validated for children [28-30] and adults [30]. However, this is its first use in relation to sarcopenia. The ARFS is a summary score of the overall healthiness and nutritional quality of usual eating patterns. According to the report provided 'Guidance on Food and Nutrition Intake Output' (2016, v.1.0), the total ARFS is 73 points, which is made up of vegetables (21), fruit (12), protein foods: meat/flesh (7), protein foods: meat/flesh alternatives (6), grains, breads, cereals (13), dairy (11), water (1), and extras (2). A score $<33$ points indicates 'needs work', 3338 'getting there', 39-46 'excellent', and 47 and over 'outstanding. Thus, a higher ARFS score means healthier eating patterns and dietary intake that is of higher nutritional quality. Use of AES requires a paid subscription for each participant. 


\section{Statistical analysis}

Data is expressed as mean (SD) and frequency (\%) unless otherwise specified. Descriptive statistics were performed on continuous variables and frequency analyses on nominal variables. Continuous data was assessed for normality and parametric (independent-sample t-tests) or non-parametric (Mann-Whitney) tests were used as appropriate. Pearson correlations examined associations for sarcopenia components (muscle strength, lean mass and physical performance) with self-reported physical activity and nutritional status. The Pearson coefficient was interpreted as weak (0.1-0.3), moderate $(0.3-0.7)$ and strong $(0.7-1.0)$. A $p$ value $<0.05$ at $95 \%$ confidence intervals was considered statistically significant. All analyses were performed using IBM SPSS Statistics for Mac, version 25 (IBM Corp., Armonk, NY, USA).

\section{Results}

\section{Baseline characteristics}

Between February and March 2019, 114 subjects were recruited in four participating gyms. Given 20 participants were required per gym, Noble Park and Oakleigh achieved the target and the Forest Hill exceeded by 13 and Hawthorn by 11 . Data from 80 community-dwelling older adults, who had already been undergoing resistance training (for a little over a year, once a week on average) was collected in March-May 2019. The study profile is presented in Fig. 1.

Comparisons of baseline characteristics between HUR and conventional gym training are shown in Table 1. Three-quarters of the cohort were of White European/Australian origin, showing no significant difference between gym groups. A subgroup analysis was not possible due to small numbers in most categories. The SPPB and PASE scores showed this was a high functioning group. There was no significant difference in PASE between the gym groups but HUR gym participants had a significantly higher protein intake than the conventional gym participants. Similarly, no significant difference was observed in ARFS between the gyms, but the HUR group tended $(p=0.055)$ to have higher self-reported energy intake than the conventional group. The only significant difference in function was the HUR group took significantly longer to complete five chair stands $(p=$ 0.024) compared to the conventional gym group. This helps to explain the tendency for a lower SPPB score in the HUR group $(p=0.06)$, although both gym results are close to maximum SPPB scores, so well above values linked with poor outcomes.

Due to gender-specific cut-offs for muscle strength (HGS) and mass (ALM, ALM/BMI, ALM/ $\mathrm{h}^{2}$ ), a comparison by gender is demonstrated in Table 2. As expected, both muscle strength and mass were significantly higher in men than women $(p<0.001)$. There were no differences between the gyms.

No significant differences were observed for selfreported physical activity or ARFS between men and women. Energy intake was significantly higher in men compared to women in both HUR $(p=0.001)$ and conventional gyms $(p=0.014)$, with similar higher protein intake in men at the HUR gyms $(p=0.019)$. No differences between the gyms were observed for either men or women for self-reported physical activity, ARFS or energy intake (Table 3), although protein intake tended

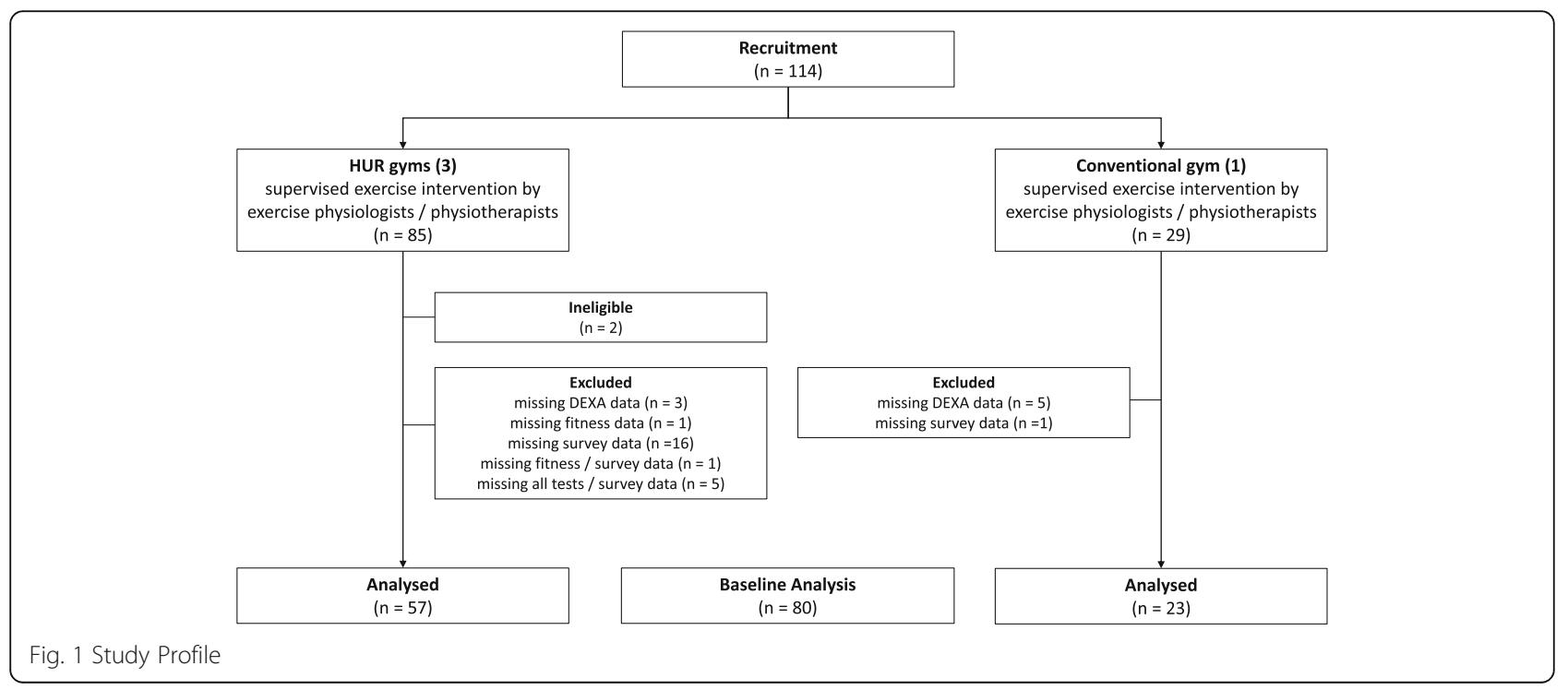


Table 1 Comparison of baseline characteristics between HUR and conventional gym training $(n=80)$

\begin{tabular}{|c|c|c|c|c|}
\hline Characteristic & & HUR $(n=57)$ & Conventional $(n=23)$ & $P$-value for difference \\
\hline \multirow[t]{3}{*}{ Demographics } & Age (yr), mean (SD) & $76(6)$ & $78(7)$ & 0.236 \\
\hline & Women, frequency (\%) & $37(65)$ & $16(70)$ & 0.690 \\
\hline & White European/Australian origin, frequency (\%) & $48(84)$ & $21(91)$ & 0.404 \\
\hline \multirow[t]{2}{*}{ Training } & Years trained, mean (SD) & $1.20(0.64)$ & $1.39(0.63)$ & 0.235 \\
\hline & Weekly gym visits, mean (SD) & $1.08(0.54)$ & $0.99(0.42)$ & 0.503 \\
\hline \multirow[t]{3}{*}{ Anthropometric measurements } & Height (cm), mean (SD) & $163.9(9.5)$ & $163.2(9.5)$ & 0.765 \\
\hline & Weight (kg), mean (SD) & $77.1(17.9)$ & $71.0(15.4)$ & 0.155 \\
\hline & BMI $\left(\mathrm{kg} / \mathrm{m}^{2}\right)$, mean (SD) & $28.65(6.02)$ & $26.46(3.76)$ & 0.055 \\
\hline \multirow[t]{2}{*}{ Muscle strength } & HGS $(k g)$, mean (SD) & $26.54(8.68)$ & $25.47(7.38)$ & 0.718 \\
\hline & $\mathrm{CS}(\mathrm{s})$, mean $(\mathrm{SD})$ & $9.93(3.98)$ & $9.02(3.48)$ & $0.024 *$ \\
\hline Lean mass & ALM (kg), mean (SD) & $19.43(5.33)$ & $18.12(4.81)$ & 0.310 \\
\hline $\mathrm{FNIH}$ & $\mathrm{ALM} / \mathrm{BMI}\left(\mathrm{kg} / \mathrm{m}^{2}\right)$, mean $(\mathrm{SD})$ & $0.69(0.17)$ & $0.68(0.15)$ & 0.945 \\
\hline EWGSOP2 & $\mathrm{ALM} / \mathrm{h}^{2}\left(\mathrm{~kg} / \mathrm{m}^{2}\right)$, mean $(\mathrm{SD})$ & $7.14(1.42)$ & $6.70(1.11)$ & 0.195 \\
\hline \multirow[t]{4}{*}{ Physical performance } & $\mathrm{GS}(\mathrm{m} / \mathrm{s})$, mean $(\mathrm{SD})$ & $1.31(0.27)$ & $1.36(0.17)$ & 0.355 \\
\hline & SPPB (score), median (IQR) & $11(2)$ & $12(0)$ & 0.060 \\
\hline & TUG (s), mean (SD) & $8.96(4.62)$ & $7.41(1.14)$ & 0.052 \\
\hline & 400 m walk (min), mean (SD) & $5.58(1.79)$ & $5.34(1.21)$ & 0.307 \\
\hline Self-reported physical performance & PASE (score), mean (SD) & $127(61)$ & $128(44)$ & 0.946 \\
\hline \multirow[t]{3}{*}{ Self-reported nutrition } & ARFS (score), mean (SD) & $36(10)$ & $36(8)$ & 0.978 \\
\hline & AES protein (g), mean (SD) & $108(39)$ & $88(27)$ & $0.029 *$ \\
\hline & AES energy $(\mathrm{kJ})$, mean $(\mathrm{SD})$ & $9698(3006)$ & $8266(2904)$ & 0.055 \\
\hline
\end{tabular}

All data are mean (SD) or frequency (\%). HUR Helsinki University Research, BMI body mass index, BMC bone mineral content, HGS hand grip strength, CS chair stand, ALM appendicular lean mass, HGS hand grip strength, GS gait speed, SPPB short physical performance battery, TUG timed up and go, FNIH Foundation for the National Institutes of Health Sarcopenia Project, EWGSOP2 European Working Group on Sarcopenia in Older People (January 2019 update), PASE Physical Activity Scale for the Elderly; AES Australian Eating Survey, ARFS Australian Recommended Food Score (obtained from the AES). Analyses are independent sample t-tests for normally distributed data and Mann-Whitney tests for non-normally distributed data; ${ }^{*} p<0.05$

to be lower in the conventional compared to the HUR gyms $(p=0.090$ and 0.059 for men and women, respectively).

\section{Associations of sarcopenia components with self-reported physical activity and nutritional status}

For HUR gym participants, Pearson associations showed that GS had a significant weak, positive relationship with PASE, indicating that a higher GS (better function) was associated with a higher PASE score (greater self- reported physical activity levels) (Table 4). ALM had no significant correlations, however $\mathrm{ALM} / \mathrm{h}^{2}$ had a significant weak, positive association with protein intake and moderate, positive association with energy intake, indicating that higher $\mathrm{ALM} / \mathrm{h}^{2}$ was associated with a greater self-reported protein/energy intake. No other significant associations were observed in HUR gym participants.

For conventional gym participants, GS also had a significant moderate, positive correlation with PASE (Table 5). The $400 \mathrm{~m}$ walk had a significant moderate

Table 2 Comparison of muscle strength and lean mass between HUR and conventional gym training by gender at baseline $(n=80)$

\begin{tabular}{llllllll}
\hline & & $\begin{array}{l}\text { HUR Men } \\
(\boldsymbol{n}=\mathbf{2 0})\end{array}$ & $\begin{array}{l}\text { Conventional Men } \\
(\boldsymbol{n}=\mathbf{7})\end{array}$ & $\begin{array}{l}\boldsymbol{P} \text {-value for } \\
\text { difference }\end{array}$ & $\begin{array}{l}\text { HUR Women } \\
(\boldsymbol{n}=\mathbf{3 7})\end{array}$ & $\begin{array}{l}\text { Conventional Women } \\
(\boldsymbol{n}=\mathbf{1 6})\end{array}$ & $\begin{array}{l}\boldsymbol{P} \text {-value for } \\
\text { difference }\end{array}$ \\
\hline $\begin{array}{l}\text { Muscle } \\
\text { strength }\end{array}$ & $\mathrm{HGS}(\mathrm{kg})$ & $34.04(8.56)$ & $32.19(7.19)$ & 0.588 & $22.49(5.52)$ & $22.53(5.38)$ & 0.979 \\
Lean mass & $\mathrm{ALM}(\mathrm{kg})$ & $23.93(4.15)$ & $23.84(4.18)$ & 0.960 & $16.99(4.22)$ & $15.61(2.25)$ & 0.128 \\
FNIH & $\begin{array}{l}\mathrm{ALM} / \mathrm{BMI} \\
\left(\mathrm{kg} / \mathrm{m}^{2}\right)\end{array}$ & $0.86(0.14)$ & $0.88(0.08)$ & 0.789 & $0.59(0.10)$ & $0.60(0.08)$ & 0.774 \\
EWGSOP2 & $\begin{array}{l}\mathrm{ALM} / \mathrm{h}^{2}(\mathrm{~kg} / \\
\left.\mathrm{m}^{2}\right)\end{array}$ & $7.96(0.84)$ & $7.97(0.86)$ & 0.991 & $6.69(1.47)$ & $6.15(0.66)$ & 0.072 \\
\hline
\end{tabular}

HUR Helsinki University Research, HGS hand grip strength, ALM appendicular lean mass, BMI body mass index, FNIH Foundation for the National Institutes of Health Sarcopenia Project, EWGSOP2 European Working Group on Sarcopenia in Older People (January 2019 update). Analyses are independent sample t-tests for normally distributed data and Mann-Whitney tests for non-normally distributed data 
Table 3 Comparison of self-reported function and nutrition between HUR and conventional gym training by gender at baseline $(n=80)$

\begin{tabular}{llllllll}
\hline & & $\begin{array}{l}\text { HUR Men } \\
(\boldsymbol{n}=\mathbf{2 0})\end{array}$ & $\begin{array}{l}\text { Conventional Men } \\
(\boldsymbol{n}=\mathbf{1 6})\end{array}$ & $\begin{array}{l}\boldsymbol{P} \text {-value for } \\
\text { difference }\end{array}$ & $\begin{array}{l}\text { HUR Women } \\
(\boldsymbol{n}=\mathbf{3 7})\end{array}$ & $\begin{array}{l}\text { Conventional } \\
\text { Women }(\boldsymbol{n}=\mathbf{1 6})\end{array}$ & $\begin{array}{l}\boldsymbol{P} \text {-value for } \\
\text { difference }\end{array}$ \\
\hline $\begin{array}{l}\text { Self-reported } \\
\text { physical activity }\end{array}$ & $\begin{array}{l}\text { PASE } \\
(\text { score) }\end{array}$ & $139(84)$ & $129(36)$ & 0.695 & $121(45)$ & $127(49)$ & 0.645 \\
$\begin{array}{l}\text { Self-reported } \\
\text { nutrition }\end{array}$ & $\begin{array}{l}\text { ARFS } \\
(\text { score })\end{array}$ & $38(11)$ & $37(6)$ & 0.760 & $34(9)$ & $35(9)$ & 0.756 \\
& $\begin{array}{l}\text { AES } \\
\text { protein (g) }\end{array}$ & 124.56 & $103(19)$ & 0.090 & $99.28(34.99)$ & $82(28)$ & 0.059 \\
& $\begin{array}{l}\text { AES } \\
\text { energy (KJ) }\end{array}$ & $11,409(2963)$ & $10,429(2106)$ & 0.359 & $8773(2630)$ & $7320(2731)$ & 0.083 \\
& & & & & & \\
\hline
\end{tabular}

HUR Helsinki University Research, PASE Physical Activity Scale for the Elderly, AES Australian Eating Survey, ARFS Australian Recommended Food Score. Analyses are independent sample t-tests for normally distributed data and Mann-Whitney tests for non-normally distributed data

negative relationship with PASE, implying that a lower $400 \mathrm{~m}$ walk time (faster walking speed) was associated with a higher PASE score (greater physical activity levels). ALM had a significant moderate, positive correlation with self-reported protein and energy intake, indicating that low lean mass is associated with low protein/energy intake. When ALM was normalised for height squared, it maintained its significant moderate, positive relationship with protein and energy intake. Consistent with HUR gym participants, there was no significant association when ALM was corrected for BMI in conventional gym participants (see Tables 3 and 4, respectively). At both HUR and conventional gyms, no significant relationship was observed either for muscle strength or lean mass measures with PASE, or muscle strength and physical performance with protein/energy intake. ARFS was not associated with any of the sarcopenia components.

\section{Discussion}

In this study, only GS (but not muscle strength) at both HUR and conventional gyms was positively associated with PASE scores, indicating higher self-reported activity is associated with better GS. This is similar to previous reports of PASE scores being positively correlated with GS [27], underlining the importance of maintaining physical activity additional to any gym sessions. Our results are inconsistent with evidence that low PASE scores, indicative of low physical activity, are related to muscle strength in older adults [31], as we did not find any association between muscle strength and PASE. It is likely that if baseline data was available, associations with strength might have been stronger, but due to participants already taking part in resistance exercise training programs designed to improve muscle strength, these associations were missing.

Rizzoli et al. [32] report that associations between selfreported and performance-based measures range from small to medium, with GS and CS among the most responsive performance-based measures. Only in the HUR gym group, $400 \mathrm{~m}$ walk was negatively correlated with PASE, indicating that higher levels of physical activity are associated with faster walking speeds and better endurance. Given the above, PASE appears to be a useful survey tool for correlation with measures within lower leg mobility/speed, and GS and $400 \mathrm{~m}$ walk continue to be positively influenced by physical activity additional to concurrent resistance training.

Table 4 Associations of self-reported sarcopenia risk, physical activity, HRQoL and nutrition with sarcopenia components at baseline for HUR gym participants $(n=57)$

\begin{tabular}{|c|c|c|c|c|c|c|c|c|c|c|}
\hline \multirow[b]{2}{*}{ Component } & & \multicolumn{2}{|c|}{ Muscle strength } & \multicolumn{3}{|c|}{ Lean mass } & \multicolumn{4}{|c|}{ Physical performance } \\
\hline & & HGS (kg) & $\mathrm{CS}(\mathrm{s})$ & ALM (kg) & $\mathrm{ALM} / \mathrm{BMI}\left(\mathrm{kg} / \mathrm{m}^{2}\right)$ & $\operatorname{ALM} / \mathrm{h}^{2}\left(\mathrm{~kg} / \mathrm{m}^{2}\right)$ & $\mathrm{GS}(\mathrm{m} / \mathrm{s})$ & SPPB (score) & TUG (s) & $400 \mathrm{~m}$ walk (min) \\
\hline \multirow[t]{2}{*}{ PASE (score) } & Pearson Coefficient & 0.220 & $0-.078$ & -0.005 & -0.203 & 0.153 & $0.275^{*}$ & 0.210 & -0.239 & -0.077 \\
\hline & $p$ & 0.101 & 0.565 & 0.968 & 0.131 & 0.257 & 0.039 & 0.117 & 0.073 & 0.567 \\
\hline \multirow[t]{2}{*}{ AES-ARFS (total score) } & Pearson Coefficient & -0.190 & -0.025 & 0.097 & -0.142 & 0.230 & -0.096 & -0.183 & 0.178 & -0.067 \\
\hline & $p$ & 0.156 & 0.854 & 0.475 & 0.292 & 0.085 & 0.475 & 0.173 & 0.184 & 0.618 \\
\hline \multirow[t]{2}{*}{ AES protein (g) } & Pearson Coefficient & 0.004 & -0.044 & 0.131 & -0.168 & $0.291^{*}$ & 0.216 & 0.047 & -0.012 & -0.109 \\
\hline & $\mathrm{p}$ & 0.977 & 0.743 & 0.330 & 0.213 & 0.028 & 0.107 & 0.729 & 0.929 & 0.420 \\
\hline \multirow[t]{2}{*}{ AES energy ( $\mathrm{kJ}$ ) } & Pearson Coefficient & 0.046 & -0.067 & 0.132 & -0.255 & $0.358^{* *}$ & 0.085 & -0.063 & 0.071 & -0.071 \\
\hline & $p$ & 0.734 & 0.621 & 0.329 & 0.055 & 0.006 & 0.531 & 0.644 & 0.598 & 0.599 \\
\hline
\end{tabular}

HUR Helsinki University Research, HGS hand grip strength, CS chair stand, ALM appendicular lean mass, BMI body mass index, SPPB short physical performance battery, TUG timed up and go, PASE Physical Activity Scale for the Elderly, AES Australian Eating Survey, ARFS Australian Recommended Food Score. All analyses are Pearson correlations; ${ }^{* *} p<0.01,{ }^{*} p<0.05$ 
Table 5 Associations of self-reported physical activity and nutrition with sarcopenia components at baseline for conventional gym participants $(n=23)$

\begin{tabular}{|c|c|c|c|c|c|c|c|c|c|c|}
\hline \multirow[b]{2}{*}{ Component } & & \multicolumn{2}{|c|}{$\begin{array}{l}\text { Muscle } \\
\text { strength }\end{array}$} & \multicolumn{3}{|c|}{ Lean mass } & \multicolumn{4}{|c|}{ Physical performance } \\
\hline & & $\begin{array}{l}\text { HGS } \\
(\mathrm{kg})\end{array}$ & CS (s) & $\begin{array}{l}\text { ALM } \\
(\mathrm{kg})\end{array}$ & $\begin{array}{l}\mathrm{ALM} / \mathrm{BMI}(\mathrm{kg} / \\
\left.\mathrm{m}^{2}\right)\end{array}$ & $\begin{array}{l}\text { ALM/ } / \mathrm{h}^{2}(\mathrm{~kg} / \\
\left.\mathrm{m}^{2}\right)\end{array}$ & $\begin{array}{l}\mathrm{GS}(\mathrm{m} / \\
\mathrm{s})\end{array}$ & $\begin{array}{l}\text { SPPB } \\
\text { (score) }\end{array}$ & $\begin{array}{l}\text { TUG } \\
\text { (s) }\end{array}$ & $\begin{array}{l}400 \mathrm{~m} \text { walk } \\
\text { (min) }\end{array}$ \\
\hline \multirow[t]{2}{*}{ PASE (score) } & $\begin{array}{l}\text { Pearson } \\
\text { Coefficient }\end{array}$ & 0.396 & -0.283 & 0.171 & -0.034 & 0.226 & $0.423^{*}$ & 0.240 & -0.351 & $-0.479^{*}$ \\
\hline & $p$ & 0.061 & 0.190 & 0.435 & 0.879 & 0.301 & 0.044 & 0.270 & 0.101 & 0.021 \\
\hline \multirow[t]{2}{*}{$\begin{array}{l}\text { AES-ARFS (total } \\
\text { score) }\end{array}$} & $\begin{array}{l}\text { Pearson } \\
\text { Coefficient }\end{array}$ & -0.011 & -0.097 & 0.007 & -0.018 & 0.003 & 0.060 & 0.144 & -0.190 & -0.144 \\
\hline & $p$ & 0.959 & 0.660 & 0.973 & 0.934 & 0.989 & 0.786 & 0.512 & 0.386 & 0.512 \\
\hline \multirow[t]{2}{*}{ AES protein $(\mathrm{g})$} & $\begin{array}{l}\text { Pearson } \\
\text { Coefficient }\end{array}$ & 0.259 & 0.090 & $0.418^{*}$ & 0.093 & $0.425^{*}$ & -0.169 & -0.077 & 0.088 & 0.048 \\
\hline & $p$ & 0.232 & 0.683 & 0.047 & 0.673 & 0.043 & 0.440 & 0.727 & 0.689 & 0.827 \\
\hline \multirow[t]{2}{*}{ AES energy $(\mathrm{kJ})$} & $\begin{array}{l}\text { Pearson } \\
\text { Coefficient }\end{array}$ & 0.134 & 0.119 & $0.435^{*}$ & 0.013 & $0.482^{*}$ & -0.169 & -0.068 & 0.104 & 0.091 \\
\hline & $p$ & 0.542 & 0.588 & 0.038 & 0.955 & 0.020 & 0.440 & 0.756 & 0.637 & 0.679 \\
\hline
\end{tabular}

HGS hand grip strength, CS chair stand, ALM appendicular lean mass, BMI body mass index, SPPB short physical performance battery, TUG timed up and go, PASE Physical Activity Scale for the Elderly, AES Australian Eating Survey, ARFS Australian Recommended Food Score. All analyses are Pearson correlations; ${ }^{* *} p<0.01$, ${ }^{*} p<0.05$

In our whole sample, the PASE mean score of $\sim 127$ was higher than reported for US (M: 103) [27], Malaysian (M: 95) [33] or Turkish community-dwelling older adults (M: 122) [34]. A higher PASE score of our cohort indicate that our participants are not only communitydwellers, but have been undertaking resistance training for over a year on average. Those who attend gyms should be encouraged to not view it as their only form of exercise, but ensure it is in addition to their regular physical activity. A recent study asked 103 Australians aged 50-92 years about sustainable lifestyles [35]. Thirty percent regarded exercise as a priority; of which $11 \%$ mentioned irregular activities (e.g., gardening and walking), another $11 \%$ purposeful exercise (e.g., gym and water aerobics) and 8\% regular exercise (e.g., golf and tennis) [35]. Boulton-Lewis et al. argue that lack of awareness of exercise benefits and barriers are not new, emphasising the importance of measuring motivation and engagement to develop strategies to enhance physical activity.

None of the sarcopenia components were associated with the ARFS total score. There is limited literature on relationship between ARFS and muscle mass and function. Past research shows that a higher ARFS is linked with higher intakes of micronutrients and lower percentage energy from total and saturated fat in middle-aged populations [36]. Based on a total score of 73 for the ARFS [30], our mean results of $\sim 36$ for both gym groups were only slightly higher than that reported in middle-aged Australian women (M: 33), suggesting that although their diet could be improved, they may be outperforming younger ages [37]. Indeed, 33 and 39\% of HUR and conventional gyms, respectively, achieved
ARFS 39 and over, which is higher than that reported (21\%) of middle-aged Australian women with ARFS over 40 [37]. Our higher ARFS results in two-thirds of both gym participants imply healthier eating patterns and higher diet quality.

Studies show that low protein and energy intake is linked with sarcopenia $[5,13]$. There is also a strong correlation between lean mass and nutritional status in older populations [38]. Lower $\mathrm{ALM} / \mathrm{h}^{2}$ was significantly associated with lower self-reported protein and energy intake in both gym groups, supporting that sufficient energy intake, and protein specifically, is essential for skeletal muscle maintenance. Our results do not show any correlations for self-reported protein/energy intake with HGS. This is inconsistent with prior research showing that since muscle function is affected by poor nutrition, HGS has become a marker of nutritional status [7-9] and an outcome predictor for nutritional interventions [9].

Again, given our participants are specifically training for strength, this may have masked any effect of poor nutrition or lower protein intakes. The HUR group had significantly higher self-reported protein intake, which may be related to the fact that they also tended to have higher BMI than the conventional gym participants. The most recent national data (2011-2012) state protein intake for the general population is around $98 \mathrm{~g} /$ day and $86 \mathrm{~g} /$ day for men in the $51-70$ and $71+$ age groups, respectively, and for women it is $78 \mathrm{~g} /$ day and $73 \mathrm{~g} /$ day, respectively [39]. Thus, our results suggest that our cohort consumed more protein than average, especially the HUR gym group. It is possible that participants are not obtaining as great a benefit from engaging in exercise 
than they would if their protein intakes were higher or of better quality (not quantity) and timed more appropriately. It is very well established, at least in younger individuals, that ingesting high-quality protein with training augments the beneficial effects [40-42]. However, older individuals require higher amounts of protein to increase protein synthesis at the same levels as a younger individual [43-45], and the recommended dietary intake (RDI) is based on not becoming deficient, rather than being an optimal dose. Nowson and O'Connell [46] report that 1.0 to $1.2 \mathrm{~g} / \mathrm{kg} /$ day dietary protein is recommended for older adults or even more for those exercising and physically active to reduce muscle loss with age. A recent meta-analysis reports that muscle mass increase required protein intakes of up to $1.6 \mathrm{~g} / \mathrm{kg} /$ day and was more effective in resistance-trained people but less effective in people over 60 years [45]. Protein synthesis is higher with whey protein, which is digested quickly and lower with casein, which is digested slowly, implying that a quick protein may be more suitable for reducing protein losses in older populations [46].

Timing of protein intake in combination with exercise also needs to be considered [46]. It has been reported that community-dwelling and frail older Dutch adults with a dietary intake of $1.1 \mathrm{~g} / \mathrm{kg} /$ day and $1.0 \mathrm{~g} / \mathrm{kg} /$ day, respectively, consumed insufficient protein at breakfast and the frail group also consumed insufficient protein at lunch $(>30 \mathrm{~g})$, which was below the intake needed for muscle protein synthesis, thus likely contributing to negative health outcomes and poorer physical activity levels [46]. As a result, there is opportunity to enhance distribution of protein consumption across the day in older populations [46]. As most participants in this study had engaged in resistance training for some time, it is likely that protein quality and timing may be affecting potential for muscle mass and function gains. Thus, guidance on improving protein quality and timing of ingestion should be provided to improve lean mass health.

It is recommended regular physical activity, in addition to existing gym-based exercises, and education on nutrition be promoted at both gyms. Practical implications are that practitioners could use strategies incorporating exercises (particularly resistance training) and appropriate nutritional advice to prevent loss of muscle mass and muscle strength. Future research should incorporate post-tests to examine effects of training.

There are some limitations in our study. Since baseline data was not available, many associations did not exist as participants may have improved their muscle mass and function with training over time. The low sample size of the conventional group and not being able to show the net effect of the interventions resulted from the crosssectional nature. The $400 \mathrm{~m}$ walk test had to be modified to a $10-\mathrm{m}$ course walked 20 times rather than the standard $20 \mathrm{~m}$ walked 10 times back and forth given available space in the gyms. Results of this study may not be generalised to the general population as subjects were limited to older exercising adults in Melbourne, Australia.

\section{Conclusion}

Older adults attending HUR and conventional gyms had similar self-reported function and nutrition (but not protein intake). Inadequate physical activity was associated with low GS and inadequate nutrition and low protein ingestion associated with low lean mas, even in older adults participating in resistance exercise training programs. Optimal physical activity and nutrition are important for maintaining skeletal muscle mass and function in older adults.

Abbreviations

AES: Australian Eating Survey; ALM: Appendicular lean mass; ARFS: Australian Recommended Food Score; BMC: Bone mineral content; BMl: Body mass index; DXA: Dual-energy X-ray absorptiometry; EWGSOP2: European Working Group on Sarcopenia in Older People (January 2019 update); GS: Gait speed; HGS: Hand grip strength; CS: Chair stand; PASE: Physical Activity Scale for the Elderly; RDI: Recommended Dietary Intake; SPPB: Short physical performance battery; TUG: Timed up and go

\section{Supplementary Information}

The online version contains supplementary material available at https://doi. org/10.1186/s12877-021-02212-y

\section{Additional file 1:.}

\section{Acknowledgements}

Data and details from this manuscript has been published as part of a Master in Science (by Research) thesis [47]. We acknowledge the research sponsor Uniting AgeWell in Melbourne for providing access to their gym facilities, their client-base and a great support from their management and staff. Many thanks go to participants, their families and carers.

\section{Authors' contributions}

EA: conceived and conducted study; data collection, analysis and interpretation, drafting the manuscript. AH, DS: study concept and contribution to data interpretation; JPR, CAG, JM and AH: contributed to data collection; HMC: contributed to data interpretation; SD: contributed to study concept. The authors read and approved the final manuscript.

\section{Funding}

Not applicable.

\section{Availability of data and materials}

The datasets used and/or analysed during the current study are available from the corresponding author on reasonable request.

\section{Declarations}

Ethics approval and consent to participate

Ethical approval for this study was obtained from the Victoria University Human Research Ethics Committee on 19 December 2018 (approval number HRE18-195). All subjects provided written informed consent before data collection.

Consent for publication

Not applicable. 


\section{Competing interests}

The authors have no competing interests to declare.

\begin{abstract}
Author details
${ }^{1}$ Institute for Health and Sport, Victoria University, Footscray, Victoria, Australia. ${ }^{2}$ Institute for Physical Activity and Nutrition, School of Exercise and Nutrition Sciences, Deakin University, Burwood, Victoria, Australia. ${ }^{3}$ Department of Medicine, School of Clinical Sciences at Monash Health, Monash University, Clayton, Victoria, Australia. ${ }^{4}$ Australian Institute for Musculoskeletal Science (AIMSS), St Albans, Victoria, Australia. ${ }^{5}$ Faculty of Physiotherapy, The National University of Colombia, Bogota, Colombia. ${ }^{6}$ College of Health Sciences, University of Texas at El Paso, El Paso, TX, USA. ${ }^{7}$ Department of Medicine-Western Health, Melbourne Medical School, The University of Melbourne, St Albans, Victoria, Australia.
\end{abstract}

Received: 8 September 2020 Accepted: 11 April 2021

\section{Published online: 26 April 2021}

\section{References}

1. Tournadre A, Vial G, Capel F, Soubrier M, Boirie Y. Sarcopenia. Joint Bone Spine. 2019;86(3):309-14. https://doi.org/10.1016/j.jbspin.2018.08.001.

2. Rosenberg IH. Summary comments. Am J Clin Nutr. 1989;50(5):1231-3. https://doi.org/10.1093/ajcn/50.5.1231.

3. Saggini R, et al. Sarcopenia in Chronic Illness and Rehabilitative Approaches. Frailty Sarcopenia. 2017:161.

4. Robinson S, Cooper C, Sayer AA. Nutrition and sarcopenia: a review of the evidence and implications for preventive strategies, in Clinical Nutrition and Aging. Apple Acad Press. 2017:3-15.

5. Fujita S, Volpi E. Nutrition and sarcopenia of ageing. Nutr Res Rev. 2004; 17(1):69-76. https://doi.org/10.1079/NRR200481.

6. Millward DJ. Nutrition and sarcopenia: evidence for an interaction. Proc Nutr Soc. 2012;71(4):566-75. https://doi.org/10.1017/S0029665112000201.

7. Chilima DM, Ismail SJ. Nutrition and handgrip strength of older adults in rural Malawi. Public Health Nutr. 2001;4(1):11-7. https://doi.org/10.1079/ PHN200050

8. Heimbürger O, Qureshi AR, Blaner WS, Berglund L, Stenvinkel P. Hand-grip muscle strength, lean body mass, and plasma proteins as markers of nutritional status in patients with chronic renal failure close to start of dialysis therapy. Am J Kidney Dis. 2000;36(6):1213-25. https://doi.org/10.1 053/ajkd.2000.19837.

9. Norman K, Stobäus N, Gonzalez MC, Schulzke JD, Pirlich M. Hand grip strength: outcome predictor and marker of nutritional status. Clin Nutr. 2011;30(2):135-42. https://doi.org/10.1016/j.clnu.2010.09.010.

10. Pratama, I. and S. Setiati. Correlation between hand grip strength and functional mobility in elderly patients. In Journal of Physics: Conference Series. 2018. IOP Publishing.

11. Benavent-Caballer V, Sendín-Magdalena A, Lisón JF, Rosado-Calatayud P, Amer-Cuenca JJ, Salvador-Coloma P, et al. Physical factors underlying the timed "up and go" test in older adults. Geriatr Nurs. 2016;37(2):122-7. https://doi.org/10.1016/j.gerinurse.2015.11.002.

12. Cruz-Jentoft AJ, Bahat G, Bauer J, Boirie Y, Bruyère O, Cederholm T, et al. Sarcopenia: revised European consensus on definition and diagnosis. Age Ageing. 2019;48(1):16-31. https://doi.org/10.1093/ageing/afy169.

13. Yanai H. Nutrition for sarcopenia. J Clin Med Res. 2015;7(12):926-31. https:// doi.org/10.14740/jocmr2361w.

14. Liao Y, Peng Z, Chen L, Zhang Y, Cheng Q, Nüssler AK, et al. Prospective views for whey protein and/or resistance training against age-related sarcopenia. Aging Dis. 2019;10(1):157-73. https://doi.org/10.14336/AD.2018. 0325.

15. Jäger R, Kerksick CM, Campbell BI, Cribb PJ, Wells SD, Skwiat TM, et al. International society of sports nutrition position stand: protein and exercise. J Int Soc Sports Nutr. 2017;14(1):20. https://doi.org/10.1186/s12970-017-01 77-8.

16. Australian Ageing Agenda. From strength to strength: provider's aged care gyms flourish. 2016; Available from: https://www.australianageingagenda. com.au/2016/06/10/from-strength-to-strength-providers-aged-care-gymsflourish/.

17. Hewitt J, Goodall S, Clemson L, Henwood T, Refshauge K. Progressive resistance and balance training for falls prevention in long-term residential aged care: a cluster randomized trial of the sunbeam program. J Am Med Dir Assoc. 2018;19(4):361-9. https://doi.org/10.1016/j.jamda.2017.12.014.
18. Uniting AgeWell. Our services. 2019; Available from: https://unitingagewell. org/.

19. Power and sample size. Calculators. 2018; Available from: https://powera ndsamplesize.com/.

20. Helsinki University Research Australia. HUR SmartCard: independent training and evidence-based operating. 2018a. Available from: https://www. huraustralia.com.au/products-services/products/hur-smart-card.

21. Helsinki University Research Australia. Pneumatic resistance. 2018b. Available from: https://www.huraustralia.com.au/know-how/pneumatic-resistance.

22. Baumgartner RN, Koehler KM, Gallagher D, Romero L, Heymsfield SB, Ross RR, et al. Epidemiology of sarcopenia among the elderly in New Mexico. Am J Epidemiol. 1998;147(8):755-63. https://doi.org/10.1093/oxfordjournals.a je.a009520.

23. Suetta, C., et al., The Copenhagen sarcopenia study: lean mass, strength, power, and physical function in a Danish cohort aged 20-93 years. Journal of Cachexia, Sarcopenia and Muscle, 2019.

24. Roberts HC, Denison HJ, Martin HJ, Patel HP, Syddall H, Cooper C, et al. A review of the measurement of grip strength in clinical and epidemiological studies: towards a standardised approach. Age Ageing. 2011;40(4):423-9. https://doi.org/10.1093/ageing/afr051.

25. Guralnik JM, Simonsick EM, Ferrucci L, Glynn RJ, Berkman LF, Blazer DG, et al. A short physical performance battery assessing lower extremity function: association with self-reported disability and prediction of mortality and nursing home admission. J Gerontol. 1994;49(2):M85-94. https://doi. org/10.1093/geronj/49.2.M85.

26. Bloch ML, Jønsson LR, Kristensen MT. Introducing a third timed up \& go test trial improves performances of hospitalized and community-dwelling older individuals. J Geriatr Phys Ther (2001). 2017;40(3):121.

27. Washburn RA, Smith KW, Jette AM, Janney CA. The physical activity scale for the elderly (PASE): development and evaluation. J Clin Epidemiol. 1993; 46(2):153-62. https://doi.org/10.1016/0895-4356(93)90053-4.

28. Burrows TL, Collins K, Watson J, Guest M, Boggess MM, Neve M, et al. Validity of the Australian recommended food score as a diet quality index for preschoolers. Nutr J. 2014;13(1):87. https://doi.org/10.1186/1475-2891-13-87.

29. Marshall S, Watson J, Burrows T, Guest M, Collins CE. The development and evaluation of the Australian child and adolescent recommended food score: a cross-sectional study. Nutr J. 2012;11(1):96. https://doi.org/10.1186/1475-2 891-11-96.

30. Collins C, Burrows T, Rollo M, Boggess M, Watson J, Guest M, et al. The comparative validity and reproducibility of a diet quality index for adults: the Australian recommended food score. Nutrients. 2015;7(2):785-98. https://doi.org/10.3390/nu7020785.

31. Curcio F, Liguori I, Cellulare M, Sasso G, Della-Morte D, Gargiulo G, et al. Physical activity scale for the elderly (PASE) score is related to sarcopenia in noninstitutionalized older adults. J Geriatr Phys Ther. 2019;42(3):130-5. https://doi.org/10.1519/JPT.0000000000000139.

32. Rizzoli R, Reginster JY, Arnal JF, Bautmans I, Beaudart C, Bischoff-Ferrari H, et al. Quality of life in sarcopenia and frailty. Calcif Tissue Int. 2013;93(2):10120. https://doi.org/10.1007/s00223-013-9758-y.

33. Ismail N, et al. The Physical Activity Scale for the Elderly (PASE) Validity and Reliability Among Community-Dwelling Older Adults in Malaysia. Asia Pac J Public Health. 2015;27(8_suppl):62S-72S.

34. Ayvat E, Kilinc M, Kirdi N. The Turkish version of the physical activity scale for the elderly (PASE): its cultural adaptation, validation, and reliability. Turk J Med Sci. 2017:47(3):908-15. https://doi.org/10.3906/sag-1605-7.

35. Boulton-Lewis GM, Buys L, Lewis CO, Vine D, Dendle K. Aging, exercise and motivating engagement. Educ Gerontol. 2019;45(6):390-400. https://doi. org/10.1080/03601277.2019.1641308.

36. Collins CE, Young AF, Hodge A. Diet quality is associated with higher nutrient intake and self-rated health in mid-aged women. J Am Coll Nutr. 2008;27(1):146-57. https://doi.org/10.1080/07315724.2008.10719686.

37. Aljadani HM, et al. The Australian recommended food score did not predict weight gain in middle-aged Australian women during six years of followup. Aust N Z J Public Health. 2013;37(4):322-8. https://doi.org/10.1111/17536405.12079.

38. Landi $\mathrm{F}$, et al. Prevalence and risk factors of sarcopenia among nursing home older residents. J Gerontol Series A. 2011;67(1):48-55.

39. Australian Bureau of Statistics. Australian Health Survey: Usual Nutrient Intakes. 2015; Available from: https://www.abs.gov.au/statistics/health/hea Ith-conditions-and-risks/australian-health-survey-usual-nutrient-intakes/latestrelease\#macronutrients. 
40. Antonio J, et al. A high protein diet $(3.4 \mathrm{~g} / \mathrm{kg} / \mathrm{d})$ combined with a heavy resistance training program improves body composition in healthy trained men and women-a follow-up investigation. J Int SocSports Nutr. 2015;12(1): 39.

41. Cribb PJ, et al. Effects of whey isolate, creatine and resistance training on muscle hypertrophy. Med Sci Sports Exerc. 2007;39(2):298-307. https://doi. org/10.1249/01.mss.0000247002.32589.ef.

42. Cribb PJ, Williams AD, Carey MF, Hayes A. The effect of whey isolate and resistance training on strength, body composition, and plasma glutamine. Int J Sport Nutr Exerc Metab. 2006;16(5):494-509. https://doi.org/10.1123/ ijsnem.16.5.494.

43. Chernoff R. Protein and older adults. J Am Coll Nutr. 2004;23(supp 6):627S305 .

44. Moore DR, et al. Protein ingestion to stimulate myofibrillar protein synthesis requires greater relative protein intakes in healthy older versus younger men. J Gerontol Series A. 2014;70(1):57-62.

45. Morton RW, Murphy KT, McKellar SR, Schoenfeld BJ, Henselmans M, Helms $\mathrm{E}$, et al. A systematic review, meta-analysis and meta-regression of the effect of protein supplementation on resistance training-induced gains in muscle mass and strength in healthy adults. Br J Sports Med. 2018;52(6):376-84. https://doi.org/10.1136/bjsports-2017-097608.

46. Nowson C, O'Connell S. Protein requirements and recommendations for older people: a review. Nutrients. 2015;7(8):6874-99. https:/doi.org/10.3390/ nu7085311.

47. Akehurst, E., Associations of Sarcopenia Components with Physical Function, Health-Related Quality of Life and Nutrition in Older Adults Performing Exercise Training. 2019 (Master's thesis, Victoria University).

\section{Publisher's Note}

Springer Nature remains neutral with regard to jurisdictional claims in published maps and institutional affiliations.

Ready to submit your research? Choose BMC and benefit from:

- fast, convenient online submission

- thorough peer review by experienced researchers in your field

- rapid publication on acceptance

- support for research data, including large and complex data types

- gold Open Access which fosters wider collaboration and increased citations

- maximum visibility for your research: over $100 \mathrm{M}$ website views per year

At $\mathrm{BMC}$, research is always in progress.

Learn more biomedcentral.com/submissions 


\section{University Library}

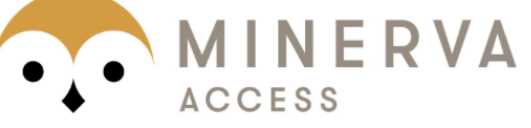

A gateway to Melbourne's research publications

Minerva Access is the Institutional Repository of The University of Melbourne

Author/s:

Akehurst, E;Scott, D;Rodriguez, JP;Gonzalez, CA;Murphy, J;McCarthy, H;Dorgo, S;Hayes, A

Title:

Associations of sarcopenia components with physical activity and nutrition in Australian older adults performing exercise training

Date:

2021-04-26

Citation:

Akehurst, E., Scott, D., Rodriguez, J. P., Gonzalez, C. A., Murphy, J., McCarthy, H., Dorgo, S. \& Hayes, A. (2021). Associations of sarcopenia components with physical activity and nutrition in Australian older adults performing exercise training. BMC GERIATRICS, 21 (1), https://doi.org/10.1186/s12877-021-02212-y.

Persistent Link:

http://hdl.handle.net/11343/278147

License:

CC BY 